\title{
Analysis of the Service Channels Building of Commercial Bank Credit Card in the Mobile Internet Age
}

\author{
Ye Gong \\ School of Management, Shanghai University \\ Shanghai Branch of China Construction Bank \\ Shanghai, China
}

\begin{abstract}
In the process of credit cards issue, commercial banks can constantly replenish card products line, launch a new business, and improve the credit card function, in addition to these, how to present these products, services and functions to customers better and allow customers to accept is also a key work. So as a bank window, the service channel development is this focus of the focus, and also an important part of the bank's IT work.
\end{abstract}

Keywords- Mobile internet, Service channels, Credit card

\section{INTRODUCTION}

Bank credit card is a simple consumer credit business with the carrier of card, granting certain credits based on the cardholder credit and financial resources. Within this limit, the cardholder can repay after the consumption and recycle credit. Because the credit card business has a certain complexity and creativity, there is a difference between traditional businesses. Credit cards center is often a relatively independent and complete process in the form of a closed loop to carry out and some banks set up a department or even set up subsidiaries.

Year 2003 is the industry recognized "China Credit Card first year", indicating that China has entered a period of credit card rapid development, from the 3 million copies to 364 million in the first half of 2013, an average annual growth rate of $61.58 \%$. With the mobile Internet as the carrier, develop their own service channels and introduce new services, which is also keen to banks currently at the forefront of innovation. ${ }^{[1]}$

Mobile Internet means that users use mobile phones, netbooks, laptops and other mobile devices, to get access in mobile communications network services and Internet services via mobile networks. Year 2012 is the explosive growth year of the Chinese mobile Internet market, the number of users of mobile devices has been beyond the desktop number, and the number of people using mobile applications grows with double rate each quarter, the mobile Internet industry shows vigorous development trend. The users' scale of 420 million mobile phone accounts for $74.5 \%$ of the overall Internet users, the status of the first Internet terminal is more stable. In the application of entertainment and social behavior, with a gradual replacement of the use of computer terminals, which greatly improves the user access environment, and improves the Internet experience, more users have enjoyed the convenience of the mobile Internet. ${ }^{[2]}$

\section{DEVELOPMENT OF COMMERCIAL BANKS IN THE MOBILE INTERNET ERA}

With the explosive development of mobile Internet, commercial banks competition with mobile banking is also not waiting up, eager to move into the era of Internet banking. Mobile banking, mobile payment and instant cross-platform, and mobile banking financial services has become the new Troika.

\section{A. Mobile bank}

Commercial banks are the first to set foot in the mobile Internet electronic banking, its most representative is mobile banking. According to domestic research institutions, China Mobile Banking research report in 2012 referred that the development of mobile banking is divided into three stages: 2000 SMS banking, WAP mobile web banking in 2004, APP's mobile client banks in 2007.

SMS banking major means that banks push information to the customer, including transaction information, account information changes, billing information, then gradually developed an interactive text messaging, which allows customers to send SMS commands for initiative inquiry information. WAP mobile banking primarily makes online banking to mobile web in the form of the show, but subject to a page showing as well as technical limitations in functionality, often not comparable to online banking. APP clients use the way of mobile applications, providing customers with a comprehensive and diverse functions.

In phone banking, domestic joint-stock commercial bank is better, other city commercial banks development is lagging behind. While paying attention to each line of mobile Internet business development, the rate of China Mobile Banking user penetration is only $4.6 \%$. Relative to the North American market penetration rate of $29.3 \%$, our mobile banking has as well as a lot of room for development.

\section{B. Wechat bank}

Market competition in the mobile Internet era is to seize the competitive entrance, including the hardware, operating system, application store, browser, communication tools, and security software. As for the financial industry, actively seizing the mobile Internet service portal is to make firstmover advantage in the mobile Internet era. In March, 2013, China Merchants Bank Credit Card Center firstly issued the 
micro customer service, in July, upgraded platform and first launched the wechat bank. So far, more than 1.2 million customers have bounded Merchants Bank credit card, and achieved benefits and reputation double harvest. Currently, many banks have followed suit and actively launched its own wechat banks and even some banks started to pay attention to cooperating with other communication tools, such as easy letter, etc., but still difficult to shake pole position of Merchants Bank.

\section{Mobile Payments}

Year 2012 can be said to be the first year of the development of mobile payments. In this year, the three mobile payment participants - banks and other financial institutions, Mobile, Telecom, China Unicom and other carriers, PayPal, Tenpay, Kara and other third-party online or offline distribution payment providers have increased investment in the mobile payment market. Earlier this year, in addition to mobile payment CUP and CUP launched CCB, $\mathrm{ABC}$ and UnionPay, China Telecom's palm still wallet and, recently, China Merchants Bank and HTC have jointly launched the China Merchants Bank equipped with mobile wallet application of NFC mobile phones. Meanwhile, China Merchants Bank even proposed the elimination of credit card in the next few years, fully ported credit card function to mobile devices in strategic objectives. ${ }^{[3]}$

Not only in the domestic but also abroad, is mobile payment in full swing. It is understood that the mainstream of the international market of mobile payment methods, including: Square card mode startups, PayPal launched PayPal Here, Google launched Google Wallet (based on NFC technology), Zipmark and so on. Where, Square's card mode attracts most attention. ${ }^{[4]}$

\section{THE PROBLEMS EXISTING IN COMMERCIAL BANKS IN THE DEVELOPMENT PROCESS OF MOBILE INTERNET SERVICE CHANNELS}

With the development of mobile Internet technology, full-time online era is coming. No matter when, where, who, what terminal will initiate a service request, the Bank shall provide all-powerful, all-encompassing, ubiquitous communication and service, providing high-quality customer experience, but there is still a long way to go.

\section{A. Lack of the main channel}

In Internet era, banks develop Internet banking, including most of the business in the online banking, and even the use of online banking channels to replace traditional outlets and telephone banking. China Merchants Bank builded a network of online banking to make up for their weaknesses. But with the advent of the mobile Internet era, the customer's surfing habits have transferred from computer to the phone. At a time when the mobile phone side of various channels, such as SMS, mobile web, mobile APP, etc., cannot compare with the online bank.

\section{B. Lack of attention to customer channel preferences}

Banks want customers to use self-service channels to complete the business, reduce labor costs and operating costs for banks, but banks often promote the self-service channel to customers, they often seem unable, customers often need to communicate with people and are reluctant to face machine. This is the lack of attention to the bank's customer channel preferences caused. Different customers or customer groups of different ages have their own tendencies in the use of the channel. Pay attention to channels audience and binding properties of channels, design more in line with customer preferences and interaction processes function, in order to attract customers and seize the customer.

\section{Lack of interoperability between channels}

In the development process of emerging channels of banks, often there is a chronological. Different channels may collaborate with different companies or develop based on different platforms, thus leading to a variety of sources.

\section{Lack of customer demand prediction in big data era}

Banks have established a large data warehouse, put emphasis on data mining and data models. But at present the data in each row are basically structured, mainly from within the bank. From the point view of analysis of the content, it is mainly dominated by post-hoc analysis and trend analysis. But with the development of mobile Internet, microblogging, wechat and other social media have been gradually changing customer behavior and ways of expression. Banks have been unable to obtain only from their own internal data to comprehensive customer information. Therefore, banks need to extend the range of data analysis to a variety of social media.

\section{E. Lack of risk prevention and control}

The customer experience brought by mobile Internet era is mainly fast, easy, and convenient at the same time but often at the expense of the customer at the expense of safety. Such as the current mobile payment, mobile payment treasure, etc., basically without the customer to enter a password that you can complete the payment, once the phone is lost without timely reporting the loss, no criminals in difficult circumstances to complete fraudulent, customers bear the economic loss, and this loss is very difficult to get paid. As a service industry in the country, banking and financial institutions bear certain social responsibilities, need to protect the economic interests of the majority of our cardholders not be harmed.

\section{COMMERCIAL BANK MOBILE INTERNET CHANNEL DEVELOPMENT STRATEGY}

\section{A. The main channel of designing the mobile Internet}

The main channel to clear mobile Internet: select the current bank mobile Internet channel, according to the situation analysis to analyze advantage of channels, weaknesses, opportunities and threats, and ultimately select a full-service coverage for the main channels. Personally thinking, the mobile Internet service channels (mobile APP, wechat, SMS), the phone APP can be used as the main channel for development. Clear that the main channels and non-main channels should be deployed which business 
functions: in customer perspective, with the main line of bank credit card, sort out all the business from a credit card. Then divide according to the degree of risk and the business difficulty, the business is divided into low difficulty low-risk, low difficulty high risk, low-risk difficult, high-risk difficult four types. ${ }^{[6]}$

\section{B. Use data analysis to determine the customer channel preferences and customer demand forecasts}

\section{1) Analysis of customer channel preferences}

The current analysis of the advantages and disadvantages of existing channels to identify the characteristics of different sources. Human interaction such as telephone banking, network face to face interaction, online banking and other human-to-machine interaction. To have the distinctive features of the user's channels feature analysis, analysis of customer's age, lifestyle, work, and operational processes. Summarize the different channels of different customer groups.

Mobile Internet has cleared each channel's characteristics, in addition, real-time determine a new customer belongs to which customers, by matching relations and bank channels suitable for customer preferences.

\section{2) Customer demand forecast}

Customer demand includes two aspects, the purpose of the customer and emotions.Customer contact banks are on purpose, by customer characteristics, past behavior and the combination of the contact to identify customer needs. After this time, if the bank can timely feedback, its guest operating experience can only get much better.

\section{Use the mobile Internet channel to change the traditional mode of service}

First, based on the banking network conversion to local service, traditional service model is the establishment of the bank's service network, through the network into the community, into the countryside, into the household, bringing financial services to the people of convenience. However, with the accelerated pace of modern society, customers need banking services anytime and anywhere, rather than take the time to network, service status queues do business.

Second, based on the bank's own business transformation services based on customer needs: the traditional functions of the bank is to provide financial services. Today financial services have not only a simple deposit and loan business, but need to be able to provide financial and non-bank financial one-stop service, the cross-border services. ${ }^{[7]}$

\section{Mobile Internet channel and complementary advantages}

Currently a service business is often cross-channel. How do interoperability, user account should first make interoperability between channels, which means customers can use an account across multiple channels without using different applications on the device of a bank. Followed by access channels between each other, that is, under the premise of a full assessment of customer needs, design the entrance to another access channel in a service channel. The final step is the channel between the complementary advantages, mutual access channels aim is to be able to pass the advantages of other sources to make up for their weaknesses, so that the customers are in a more coherent service channel.

\section{E. Focus on changes in the industry and innovative mobile Internet}

Focus on development of new technologies: development of new technologies to bring the mobile Internet era of development banks and credit cards. Such as mobile payment, near-field payments, etc., is to bring a virtual credit card. The integration of multi-screen in smart set-top box technology enables home banking services. Secondly, the future development of $4 \mathrm{G}$ technology and the popularity of wearable devices require banks focus on innovation of new technologies to improve the sense of innovation. Focus on industry policy changes: the mobile Internet is not only an ever-changing technology industry, but also need to continue to support or correct.

\section{F. Put emphasis on risk prevention construction}

\section{1) before matter}

The use of new technology to improve risk prevention. For example, currently, the fingerprint recognition technology introduced in IPHONE5, where customers can use mobile banking, wechat banking and mobile payments, which is convenient for identification verification process with high security. In addition, banks can also introduce iris voiceprint technology in the mobile Internet channel, through biometric of people, determine the identity of the customer, without affecting the convenient advantage of the situation to ensure the safety of customers.

\section{2) in matter}

Strengthen the business integrity for customer's reporting the loss. Originally, banks base on customer need for a corresponding service shutdown. But now if a phone is stolen or lost, banks should have a comprehensive risk prevention acumen, check out all the features of customerrelated payments, such as mobile wallet, third-party payment, wechat pay, etc.

\section{3) after matter}

Providing customers with an appropriate degree of fault tolerance in policy: As a service organization, bank should give a certain degree of care and help for property loss of customers, which includes the amount and time fault tolerance. Firstly, the bank should pay the loss of customers in the period before the economic loss payment. Secondly, the loss of customers's large sums of money, the bank can work with the insurance company to recover some losses.

\section{CONCLUSION}

This paper discusses that from the departure of the bank credit card customer service and experience, how to develop mobile Internet channels. In this paper, the biggest challenge is the changing era of mobile Internet. Internet companies are currently moving to seize the entrance, to develop their own platform strategy. Little do they know, in the next three years, no company is willing to affix APP label. So for, to discuss 
any strategic for banks in mobile Internet era is temporary and requires constant correction.

\section{References}

[1] Baidu library. Market Analysis of China's Commercial Bank Credit Card [EB/OL]. (2012-09). http://wenku.baidu.com.

[2] China's Mobile Internet Industry Annual Report(2012-2013) [EB/OL]. (2013-08). http://www.iresearch.cn/.

[3] China's Mobile Banking Research Report [EB/OL]. (2013-01). http://www.iresearch.cn/.

[4] Liu C. Research on Trends and Key Technologies of Small Satellites [J]. International Journal of Science, 2014, 1(2): 38-42.
[5] Gao P. Development and Trend of Mobile Payments Abroad [J] Chinese credit card, 2013,07: 23-31.

[6] Liu C. Mixed $\mathrm{H}_{2} / \mathrm{H}_{\infty}$ control for a satellite based on LMI[C]. // Mechatronics and Control (ICMC), 2014 IEEE International Conference on. IEEE, 2014: 2114-2118.

[7] Dong Z. Mobile Internet: redefining the credit card services [EB / OL] (2013-03-26)

[8] http://www.tmtpost.com/. 